\title{
KESETARAAN GENDER PADA RUMAH TANGGA PETANI PADI SAWAH DI KECAMATAN GADING REJO KABUPATEN PRINGSEWU
}

\author{
(Gender Equality in Rice Household Farmers, Gading Rejo Sub-District, \\ Pringsewu District)
}

\section{Indah Nurmayasari ${ }^{1 *}$, Abdul Mutolib ${ }^{1}$, Nur Alfi Laila Damayanti ${ }^{1}$ dan Yuli Safitri ${ }^{1}$}

\author{
${ }^{1}$ Program Studi Penyuluhan Pertanian, Fakultas Pertanian Universitas Lampung, \\ Jalan Sumantri Brojonegoro No 1 Rajabasa Bandar Lampung \\ *E-mail korespondensi: indahnurma1@gmail.com
}

Received: 26 August2019; Revised: 23 October 2019; Accepted: 5 November 2019

\begin{abstract}
Abstrak
Penelitian bertujuan untuk mengetahui peran perempuan dan faktor-faktor yang mempengaruhi kesetaraan gender dalam rumah tangga petani padi sawah di Pekon Wonodadi Kecamatan Gading Rejo Kabupaten Pringsewu. Penelitian menggunakan pendekatan kualitatif dengan 30 sampel petani padi sawah. Data yang digunakan adalah data primer dan data sekunder. Analisis data menggunakan pendekatan kesetaraan gender model Harvard. Tingkat kesetaraan gender dalam rumah tangga petani padi sawah diukur melalui pendekatan profil aktifitas yang meliputi: 1) pembagian kerja reproduktif, 2) pembagian kerja produktif, dan 3) pembagian kerja social. Profil akses dan kontrol terhadap sumberdaya dan manfaat diidentifikasi melalui: 1) tingkat kesetaraan dalam akses terhadap sumberdaya, 2) tingkat kesetaraan dalam akses terhadap manfaat, 3) tingkat kesetaraan dalam kontrol terhadap sumberdaya, dan 4) tingkat kesetaraan dalam kontrol terhadap manfaat. Penelitian dilaksanakan pada bulan Agustus hingga September 2019. Hasil penelitian memberikan gambaran bahwa aktivitas usahatani padi sawah baik dalam kegiatan produktif, maupun sosial didominasi oleh laki-laki. Perempuan dominan dalam kegiatan reproduktif. Kesetaraan gender dalam akses dan kontrol terhadap sumber daya dan manfaat didominasi laki-laki. Faktor-faktor yang memengaruhi kesetaraan gender meliputi: faktor budaya, tingkat pendidikan, ketidakpercayaan diri perempuan, dan tingkat ekonomi atau pendapatan rumah tangga petani padi sawah.
\end{abstract}

Kata kunci : akses, budaya, gender, kontrol, dan petani padi

\begin{abstract}
The study aims to determine the role of women and the factors that influence gender equality in the households of lowland rice farmers in Pekon Wonodadi, Gading Rejo District, Pringsewu Regency. The study used a qualitative approach with 30 samples of rice farmers. The data used are primary data as well as secondary data. Data analysis uses the Harvard gender equality approach. The level of gender equality in rice farmer households is measured through an activity profile approach which includes: 1) division of reproductive work, 2) division of productive work, and 3) division of social work. Profiles of access and control of resources and benefits are identified through the levels of equality in: (1) access to resources, (2) access to benefits, (3) control of resources, and 4) control of benefits. The study was conducted in August to September 2019. The results of the study illustrate that the activities of rice farming in both productive and social activities are dominated by men. Women are dominant in reproductive activities. Gender equality in access and control over resources and benefits is dominated by men. Factors that influence gender equality include: cultural factors, education level, women's lack of confidence, and household income of rice farmers.
\end{abstract}

Keywords: access, culture, gender, control, and rice farmers 


\section{PENDAHULUAN}

Perbedaan gender menitikberatkan pada stereotype budaya di mana laki-laki dan perempuan dibedakan sesuai dengan perannya masing-masing yang dikonstruksikan oleh kultur setempat yang berkaitan dengan peran, sifat, kedudukan, dan posisi dalam masyarakat tersebut disebut dengan istilah gender (Rusni, 2015). Laki-laki dan perempuan memiliki peranan gender yang berbeda. Demikian juga pembagiaan peran dalam rumah tangga petani. Hasil penelitian Arkaniyati (2010) dan Nurmayasari et a. (2020) menunjukkan bahwa kegiatan usahatani merupakan kegiatan produktif yang melibatkan laki-laki dan perempuan dengan peranan yang bervariasi. Selain analisis peran gender, relasi antara lakilaki dan perempuan juga dapat dianalisis melalui perbedaan akses terhadap sumber daya. Tingkat akses sumber daya akan mempengaruhi kontrol dan manfaat serta partisipasi masing-masing pihak. Berbagai analisis relasi gender ini mengarah kepada tingkat keadilan dan kesetaraan gender pada berbagai tingkat masyarakat terutama pada tingkat terkecil yakni rumah tangga.

Dalam studi gender pengambilan keputusan oleh perempuan merupakan salah satu cara untuk menunjukkan eksistensi baik itu pengambilan keputusan dalam rumah tangga maupun pengambilan keputusan terhadap bercocok tanam (Unggul, 2005). Hubungan gender pada sektor pertanian padi sawah dapat dilihat dengan adanya pembagian tugas, akses, kontrol terhadap sumberdaya, antara laki-laki dan perempuan seperti dapat dilihat dalam hal pengolahan tanah, penanaman, pemeliharaan, hingga panen dan pasca panen.

Keterlibatan setiap anggota keluarga dalam pengelolaan usaha tani padi sawah sangat diperlukan untuk membantu menyelesikan pekerjaan keluarga. Dalam hal apapun, keterlibatan perempuan sangatlah penting baik dalam kegiatan rumah tangga maupun kegiatan ekonomi yang dapat menunjang pendapatan keluarga menjadi lebih besar. Secara langsung maupun tidak langsung kaum perempuan terlibat dan bertanggung jawab dalam pengelolaan usaha tani yang berhubungan dengan kesejahteraan keluarga.

Kajian analisis gender pada rumah tangga petani menjadi referensi bagi penelitian ini, seperti, Pratiwi (2007) dengan analisis gender pada rumah tangga petani monokultur sayur, menyimpulkan bahwa peran laki-laki lebih dominan dari pada perempuan maka terjadi ketidakadilan gender sehingga dapat menyebabkan perempuan semakin termarjinalisasi. Putri (2010) tentang relasi gender pada rumah tangga petani sayuran dataran rendah, menyimpulkan bahwa relasi gender pada rumah tangga petani sayur dipengaruhi oleh tiga faktor yaitu karakteritik pribadi petani, aksesibilitas informasi dan lingkungan. Pada usahatani padi sawah, Yunus et. al (2016) serta Salman (2017) menemukan bahwa telah terjadi perubahan kelembagaan pada berbagai tahapan kerja yang salah satu efeknya adalah terpinggirkannya peran perempuan dalam usahatani padi sawah. Penelitian ini akan melanjutkan penelitian terdahulu terkait kesetaraan gender pada petani padi khususnya di Provinsi Lampung.

Kabupaten Pringsewu merupakan salah sentra padi di Provinsi Lampung. Data BPS Provinsi Lampung (2019) menyebutkat bahwa pada tahun 2018 produksi padi Kabupaten Pringsewu sebesar 125.902 ton dengan luas lahan sekitar 23.317 hektar. Produktivitas padi Kabupaten Pringsewu sebesar 5,4 ton/ha atau salah satu yang tertinggi di Provinsi Lampung. Di tingkat Kabupaten, Kecamatan Gading Rejo adalah sentra padi di Provinsi Lampung dengan luas panen 6.692 ha dengan produksi 36.440 ton dan produktivitas sebesar 5,44 ton/ha. Tingginya potensi padi di Kecamatan Gading Rejo menjadikan penelitian tentang keterlibatan gender dalam usahatani padi menarik dilakukan. Penelitian ini bertujuan untuk mengetahui peran perempuan dan faktorfaktor yang mempengaruhi kesetaraan gender dalam rumah tangga petani padi sawah di Kecamatan Gading Rejo Kabupaten Pringsewu.

\section{METODE PENELITIAN}

\section{Lokasi dan Waktu Penelitian}

Penelitian dilaksanakan di Pekon Wonodadi Kecamatan Gadingrejo, Kabupaten Pringsewu, Lampung, Indonesia. Penelitian dilaksanakan pada bulan Agustus hingga September 2019. Pekon Wonodadi memiliki keunggulan pada hasil pertanian khusunya padi sawah. Pertanian sawah merupakan sumber penghasilan utama masyarakat di Pekon Wonodadi. 


\section{Metode Penelitian}

Penelitian menggunakan pendekatan penelitian kualitatif. Peneliti menggunakan perspektif dari partisipan sebagai gambaran yang diutamakan dalam memperoleh hasil penelitian. Pengambilan sampel metode wawancara dengan kuesioner. Pendekatan kualitatif digunakan untuk menemukan dan memahami apa yang tersembunyi dibalik fenomena yang sulit dipahami dan dijelaskan secara kuantitatif (Manginsela, 2017). Jumlah sampel dalam penelitian ini adalah 30 responden.

Data yang digunakan adalah data primer dan data sekunder. Data primer yaitu data diperoleh dari narasumber secara langsung menggunakan metode wawancara. Data sekunder diperoleh melalui laporan dari buku, jurnal yang terkait dengan penelitian ini. Tahapan penelitian yang dilakukan adalah tahap invention (tahap pra-lapangan yang berisi menyusun, memilih lokasi, serta memilih narasumber penelitian), tahap discovery (tahap pelaksanaan pengambilan data di lapangan), dan tahap explanation (tahap pengolahan data, mengorganisir, dan mendeskripsikan data yang diperoleh) (Anggito dan Setiawan, 2018).

\section{Analisis data}

Analisis data menggunakan analisis Harvard. Pendekatan analisis harvard mengumpulkan data skala mikro atau skala rumah tangga dan masyarakat. Kerangka ini terdiri atas tiga elemen pokok, yaitu profil aktivitas, profil akses dan kontrol terhadap sumberdaya dan manfaat, dan faktor yang mempengaruhi (March et al.1999)

a) Profil aktivitas, dalam profil aktivitas dikelompokkan menjadi peran produktif, reproduktif dan sosial. Peran gender adalah peran yang diciptakan masyarakat bagi perempuan dan laki-laki. Dalam bentuk ideal peran adalah suatu kombinasi dari peran yang dirumuskan dan peran yang diharapkan ditambah dengan peran yang diterima (Hubeis, 2010). Profil aktivitas antara laki-laki dan perempuan dalam rumah tangga menjadi salah satu penilaian dalam kesetaraan gender. Aktivitas mampu memberi gambaran yang cukup jelas bagaimana laki-laki dan perempuan membagi perannya di dalam rumah tangga (Martiany, 2012). b) Profil akses dan kontrol terhadap sumberdaya dan manfaat, dalam profil akses merujuk pada kesempatan untuk menggunakan sumber daya produktif dan manfaat yang didapatnya tanpa memiliki wewenang untuk mengambil keputusan terhadap cara penggunaan dan hasil sumber daya tersebut dalam program. Sementara itu, profil kontrol merujuk pada kewenangan untuk mengambil keputusan atas penggunaandan hasil sumber daya dan manfaat yang telah didapat. Individu yang mencapai tingkat kontrol dapat membuat keputusan mengenai penggunaan sumberdaya dan apapun yang bisa dijualnya (March et al. 1999).

c) Faktor-faktor yang mempengaruhi, elemen ini adalah mengurutkan faktor-faktor yang memberikan pengaruh terhadap perbedaan gender dalam pembagian kerja, akses dan kontrol terhadap sumberdaya dan manfaat. Faktor yang mempengaruhi, termasuk relasi gender, norma komunitas, kepercayaan, budaya, kondisi demografi, struktur institusional, kondisi ekonomi dan faktor internal dan eksternal politik (March et al. 1999).

\section{HASIL DAN PEMBAHASAN}

\section{Gambaran Umum Responden}

Usahatani padi sawah memerlukan tenaga kerja dalam pengelolaannya termasuk keikutsertaan seorang perempuan (istri) sebagai tenaga kerja dalam keluarga. Responden didominasi kaum perempuan dengan usia paling tua yakni 65 tahun, sedangkan petani yang usia muda yakni 40 tahun dengan rata-rata usia responden 50 tahun. Usia produktif seseorang adalah dari umur 15 hingga 64 tahun (Mantra, 2004). Responden seluruhnya bersuku jawa. Rata-rata pendidikan responden adalah Sekolah Dasar dengan rata-rata jumlah anggota keluarga sebanyak 4 orang.

\section{Pembagian Kerja Reproduktif}

Pekerjaan reproduktif dalam rumah tangga petani padi sawah meliputi kegiatan domestik yang biasa dilakukan di dalam rumah guna memenuhi segala kebutuhan anggota keluarga berbentuk pelayanan dan fasilitas dalam rumah tangga. 
Tabel 1 memperlihatkan bahwa kegiatan reproduktif rata-rata dilakukakan oleh perempuan dengan persentase kontribusi 75,00\% meliputi kegiatan membersihkan rumah, mengasuh anak, memasak, mencuci piring dan perabotan rumah tangga, mendampingi anak belajar dan berbelanja di dapur. Peran laki-laki secara utuh hanya berkontibusi sebesar 10\% yaitu dalam kegitan antar jemput anak. Kegiatan lain juga dilakukan secara bersama namun tetap didominasi perempuan dengan persentase sebesar $11,25 \%$. Secara umum kesetaraan gender dalam kegiatan reproduktif masih banyak ditanggung dan dikerjakan oleh perempuan. Perempuan identik dengan pekerjaan domestik, padahal perempuan dan laki-laki memiliki kesempatan dan peluang hidup yang sama dalam rumah tangga (Pawitasari, 2015).

Tabel 1. Pembagian kerja reproduktif rumah tangga petani padi sawah di Pekon Wonodadi

\begin{tabular}{lcccccc}
\hline \multicolumn{1}{c}{$\begin{array}{c}\text { Kegiatan } \\
\text { Reproduktif }\end{array}$} & $\mathrm{L}$ & $\mathrm{BDL}$ & $\mathrm{B}$ & $\mathrm{BDP}$ & $\mathrm{P}$ & Total \\
\cline { 2 - 7 } & 0 & 0 & 0 & 20 & 80 & 100 \\
\hline $\begin{array}{l}\text { Membersihkan } \\
\text { rumah }\end{array}$ & 0 & 0 & 0 & 30 & 70 & 100 \\
$\begin{array}{l}\text { Mengasuh anak } \\
\text { Memasak }\end{array}$ & 0 & 0 & 0 & 10 & 90 & 100 \\
$\begin{array}{l}\text { Mencuci pakaian } \\
\text { Mencuci piring- } \\
\text { perabotan RT }\end{array}$ & 0 & 0 & 0 & 0 & 100 & 100 \\
$\begin{array}{l}\text { Mendampingi } \\
\text { anak belajar }\end{array}$ & 0 & 0 & 0 & 0 & 100 & 100 \\
$\begin{array}{l}\text { Antar jemput } \\
\text { anak }\end{array}$ & 80 & 10 & 10 & 0 & 0 & 100 \\
$\begin{array}{l}\text { Berbelanja } \\
\text { keperluan dapur }\end{array}$ & 0 & 0 & 0 & 20 & 80 & 100 \\
\hline Rata-rata & 10 & 1,25 & 2,5 & 11,25 & 75 & 100 \\
\hline Keterangan & & & & & & 100 \\
\hline
\end{tabular}

Keterangan"

Laki-Laki (L), Bersama Dominasi Laki-laki (BDL), Bersama (B), Bersama Dominasi Permpuan (BDP), Perempuan $(P)$.

\section{Pembagian Kerja Produktif}

Peran produktif dalam rumah tangga biasanya identik dengan pekerjaan yang memberikan manfaat secara finansial guna memenuhi kebutuhan keluarga. Dalam usahatani padi sawah terdapat kegiatan untuk menghasilkan suatu produk guna memenuhi kebutuhan hidup keluarga. Pengelolaan usahatani memerlukan tenaga kerja termasuk keterlibatan perempuan.

Kegiatan produksi pada usahatani padi sawah didominasi laki-laki dengan persentase sebesar $86,25 \%$, terdapat kegiatan produksi yang dilakukan sepenuhnya oleh laki-laki seperti pengairan, pemupukan, dan pengendalian organisme pengganggu tanaman (OPT). Kegitan usahatani padi sawah yang dilakukan bersama namun tetap didominasi laki-laki mencapai persentase sebesar 12,50\% yang meliputi kegiatan pengolahan lahan, pindah tanam, panen padi dan pengolahan lahan pasca panen. Kegiatan usahatani yang dilakukan secara bersama-sama yang memiliki persentase terkecil yaitu pengolahan pasca panen yang dilakukan bersama sebesar 1,25\% .

Tabel 2. Pembagian kerja produktif rumah tangga petani padi sawah di Pekon Wonodadi

\begin{tabular}{|c|c|c|c|c|c|c|}
\hline \multirow{2}{*}{$\begin{array}{l}\text { Kegiatan } \\
\text { Produktif }\end{array}$} & $\overline{\mathrm{L}}$ & BDL & $\mathrm{B}$ & BDP & $\mathrm{P}$ & Total \\
\hline & $\%$ & $\%$ & $\%$ & $\%$ & $\%$ & $\%$ \\
\hline $\begin{array}{l}\text { Persemaian/ } \\
\text { pembibitan padi }\end{array}$ & 80 & 20 & 0 & 0 & 0 & 100 \\
\hline $\begin{array}{l}\text { Pengolahan } \\
\text { lahan sawah }\end{array}$ & 90 & 10 & 0 & 0 & 0 & 100 \\
\hline $\begin{array}{l}\text { Pindah tanam } \\
\text { bibit }\end{array}$ & 70 & 30 & 0 & 0 & 0 & 100 \\
\hline $\begin{array}{l}\text { Pengairan/irigasi } \\
\text { tanaman padi }\end{array}$ & 100 & 0 & 0 & 0 & 0 & 100 \\
\hline Pemupukan padi & 100 & 0 & 0 & 0 & 0 & 100 \\
\hline $\begin{array}{l}\text { Pengendalian } \\
\text { OPT tanaman } \\
\text { padi }\end{array}$ & 100 & 0 & 0 & 0 & 0 & 100 \\
\hline Panen padi & 80 & 20 & 0 & 0 & 0 & 100 \\
\hline $\begin{array}{l}\text { Pengolahan } \\
\text { pasca panen }\end{array}$ & 70 & 20 & 10 & 0 & 0 & 100 \\
\hline Rata-rata & 86,25 & 12,5 & 1,25 & 0 & 0 & 100 \\
\hline
\end{tabular}

\section{Pembagian Kerja Sosial}

Peran sosial dalam rumah tangga biasanya berkaitan bagaimana anggota rumah tangga memiliki kontribusi dan peran di depan publik, memiliki interaksi yang luas dalam kegiatan sosial masyarakat. Kegiatan sosial sangat penting bagi setiap individu, karena pada dasarnya manusia sebagai makhluk sosial sangat membutuhkan manusia lainnya untuk memenuhi kebutuhan hidupnya.

Pembagian kerja sosial didominasi oleh laki-laki dengan persentase 51, 67\% yang meliputi keterlibatan dalam rapat kelompok tani, penyuluhan pertanian, dan kumpulan Pekon. Kegiatan yang dilakukan bersama sebesar 20,00\% adalah kegiatan pengajian. Peran perempuan dalam kegiatan sosial sebesar $18,30 \%$ yang meliputi kegiatan yang bersifat domestik seperti memasak dalam hajatan dan arisan. 
Tabel 3. Pembagian kerja sosial rumah tangga petani padi sawah di Pekon Wonodadi

\begin{tabular}{|c|c|c|c|c|c|c|}
\hline Kegiatan & $\mathrm{L}$ & BDL & B & BDP & $\mathrm{P}$ & Total \\
\hline Sosial & $\%$ & $\%$ & $\%$ & $\%$ & $\%$ & $\%$ \\
\hline Arisan & 30 & 0 & 0 & 10 & 60 & 100 \\
\hline $\begin{array}{l}\text { Rapat } \\
\text { kelompok } \\
\text { Tani }\end{array}$ & 90 & 10 & 0 & 0 & 0 & 100 \\
\hline $\begin{array}{l}\text { Penyuluhan } \\
\text { pertanian }\end{array}$ & 90 & 10 & 0 & 0 & 0 & 100 \\
\hline Hajatan & 10 & 0 & 40 & 0 & 50 & 100 \\
\hline Pengajian & 20 & 0 & 80 & 0 & 0 & 100 \\
\hline $\begin{array}{l}\text { Kumpul } \\
\text { Pekon } \\
\text { (RT/RW) }\end{array}$ & 70 & 30 & 0 & 0 & 0 & 100 \\
\hline Rata-rata & 51,667 & 8,33 & 20 & 1,667 & 18,333 & 100 \\
\hline
\end{tabular}

\section{Akses dan Kontrol terhadap Sumber Daya dan Manfaat}

Profil akses dan kontrol terhadap sumberdaya dan manfaat, dalam profil akses merujuk pada kesempatan untuk menggunakan sumber daya produktif dan manfaat yang didapatnya tanpa memiliki wewenang untuk mengambil keputusan terhadap cara penggunaan dan hasil sumber daya tersebut dalam program. Profil kontrol merujuk pada kewenangan untuk mengambil keputusan atas penggunaandan hasil sumber daya dan manfaat yang telah didapat. Peran dan kedudukan lakilaki dan perempuan merupakan mitra sejajar yang harus memiliki kesetaraan yang sama dalam berbagai sektor kehidupan. Ini tidak terlepas dari kemampuan antara laki-laki dan perempuan dalam hak akses dan kontrol dari sumberdaya dan manfaat yang mereka miliki (Handayani, 2015).

\section{Tingkat Kesetaraan Gender dalam Akses terhadap Sumber Daya}

Kesetaraan merupakan suatu kesamaan kondisi bagi laki-laki dan perempuan untuk memperoleh kesempatan serta hak-haknya sebagai manusia (Soejipto, 2010). Tingkat kesetaraan dalam akses terhadap sumber daya artinya ditujukan kepada suatu indikator yang melihat kesetaraan antara hak dan kewajiban manusia dalam kegiatan mengolah sumber daya dalam keluarga.

Akses terhadap sumber daya didominasi kaum laki-laki dengan persentase 87,78\%. Kegiatan yang dilakukan secara bersama-sama antara laki-laki dan perempuan dalam akses terhadap sumber daya sebesar 2,22\%. Akses sumberdaya dilakukan bersama-sama tetapi dominasi laki-laki yang meliputi pengadaan benih, penjemuran gabah, dan perontokan padi.

Tabel 4. Tingkat kesetaraan dalam akses terhadap sumber daya pada rumah tangga petani padi sawah di Pekon Wonodadi

\begin{tabular}{|c|c|c|c|c|c|c|}
\hline \multirow[t]{2}{*}{$\begin{array}{c}\text { Akses terhadap } \\
\text { Sumber Daya }\end{array}$} & $\mathrm{L}$ & $\begin{array}{c}\mathrm{BD} \\
\mathrm{L}\end{array}$ & B & BDP & $\bar{P}$ & Total \\
\hline & $\%$ & $\%$ & $\%$ & $\%$ & $\%$ & $\%$ \\
\hline $\begin{array}{l}\text { Alat mesin } \\
\text { pengolahan } \\
\text { lahan }\end{array}$ & 90 & 10 & 0 & 0 & 0 & 100 \\
\hline $\begin{array}{l}\text { Pengadaan } \\
\text { benih }\end{array}$ & 80 & 20 & 0 & 0 & 0 & 100 \\
\hline $\begin{array}{l}\text { Membantu } \\
\text { pembuatan } \\
\text { ubinan padi }\end{array}$ & 90 & 10 & 0 & 0 & 0 & 100 \\
\hline $\begin{array}{l}\text { Pengadaan air } \\
\text { untuk pengairan }\end{array}$ & 100 & 0 & 0 & 0 & 0 & 100 \\
\hline $\begin{array}{l}\text { Bantuan alat } \\
\text { penyiangan dan } \\
\text { pemanenan }\end{array}$ & 100 & 0 & 0 & 0 & 0 & 100 \\
\hline $\begin{array}{l}\text { Membeli pupuk } \\
\text { dan pestisida }\end{array}$ & 100 & 0 & 0 & 0 & 0 & 100 \\
\hline $\begin{array}{l}\text { Perontokan } \\
\text { gabah padi }\end{array}$ & 70 & 30 & 0 & 0 & 0 & 100 \\
\hline $\begin{array}{l}\text { Penjemuran } \\
\text { gabah }\end{array}$ & 60 & 20 & 20 & 0 & 0 & 100 \\
\hline $\begin{array}{l}\text { Pengangkutan } \\
\text { hasil panen }\end{array}$ & 100 & 0 & 0 & 0 & 0 & 100 \\
\hline Rata-rata & 87,78 & 10 & 2,22 & 0 & 0 & 100 \\
\hline
\end{tabular}

\section{Tingkat Kesetaraan Gender dalam Akses terhadap Manfaat}

Tabel 5. Tingkat kesetaraan dalam akses terhadap manfaat pada rumah tangga petani padi sawah di Pekon Wonodadi

\begin{tabular}{|c|c|c|c|c|c|c|}
\hline Akses & $\mathrm{L}$ & BDL & $\mathrm{B}$ & BDP & $\mathrm{P}$ & Total \\
\hline $\begin{array}{l}\text { terhadap } \\
\text { Manfaat }\end{array}$ & $\%$ & $\%$ & $\%$ & $\%$ & $\%$ & $\%$ \\
\hline $\begin{array}{l}\text { Hasil } \\
\text { penjualan padi }\end{array}$ & 0 & 0 & 40 & 0 & 60 & 100 \\
\hline $\begin{array}{l}\text { Merasakan } \\
\text { uang hasil }\end{array}$ & 10 & 0 & 80 & 0 & 10 & 100 \\
\hline $\begin{array}{l}\text { Keperluan } \\
\text { rumah tangga }\end{array}$ & 10 & 0 & 0 & 60 & 30 & 100 \\
\hline $\begin{array}{l}\text { Memenuhi } \\
\text { kebutuhan } \\
\text { makan }\end{array}$ & 0 & 0 & 0 & 80 & 20 & 100 \\
\hline $\begin{array}{l}\text { Pelatihan } \\
\text { penanganan } \\
\text { pasca panen }\end{array}$ & 80 & 0 & 20 & 0 & 0 & 100 \\
\hline $\begin{array}{l}\text { Mengakses } \\
\text { kekuatan } \\
\text { politik }\end{array}$ & 70 & 20 & 10 & 0 & 0 & 100 \\
\hline Rat-rata & 28,33 & 3,33 & 25 & 23,333 & 20 & 100 \\
\hline
\end{tabular}


Tingkat kesetaraan gender dalam akses terhadap manfaat bertujuan untuk melihat kesetaraan dari indikator pemanfaatan hasil usahatani. Akses perempuan secara penuh terhadap manfaat dari usahatani padi sawah sebesar $20,00 \%$ yang meliputi kegiatan hasil penjualan padi, keperluan rumah tangga, memenuhi kebutuhan makan, dan merasakan/memanfaatkan uang hasil penjualan padi. Kesetaraan gender yang dilakukan secara bersama-sama sebesar $25,00 \%$.

\section{Tingkat Kesetaraan Gender dalam Kontrol terhadap Sumber Daya}

Tingkat kesetaraan gender dalam kontrol terhadap sumber daya dilihat dari bagaimana pengawasan laki-laki atau perempuan dalam membuat keputusan terhadap kegiatan usahatani. Tingkat kesetaraan dilihat dari partisipasi antara laki-laki dan perempuan dalam menentukan keputusan dalam usahatani padi sawah.

Tabel 6. Tingkat kesetaraan dalam kontrol terhadap sumber daya pada rumah tangga petani padi sawah di Pekon Wonodadi

\begin{tabular}{|c|c|c|c|c|c|c|}
\hline Kontrol terhadap & $\mathrm{L}$ & $\mathrm{BDL}$ & $\mathrm{B}$ & BDP & $\mathrm{P}$ & Total \\
\hline Sumber Daya & $\%$ & $\%$ & $\%$ & $\%$ & $\%$ & $\%$ \\
\hline Menjual hasil panen & 60 & 20 & 20 & 0 & 0 & 100 \\
\hline $\begin{array}{l}\text { Memutuskan waktu } \\
\text { tanam }\end{array}$ & 70 & 30 & 0 & 0 & 0 & 100 \\
\hline $\begin{array}{l}\text { Tidak menjual hasil } \\
\text { panen }\end{array}$ & 60 & 20 & 20 & 0 & 0 & 100 \\
\hline $\begin{array}{l}\text { Memutuskan waktu } \\
\text { panen }\end{array}$ & 60 & 40 & 0 & 0 & 0 & 100 \\
\hline $\begin{array}{l}\text { Memutuskan } \\
\text { membeli alat } \\
\text { produksi }\end{array}$ & 80 & 20 & 0 & 0 & 0 & 100 \\
\hline Rata-rata & 66 & 26 & 8 & 0 & 0 & 100 \\
\hline
\end{tabular}

Keteranga $n$

Laki-Laki (L), Bersama Dominasi Laki-laki (BDL), Bersama (B), Bersama Dominasi Permpuan (BDP), Perempuan $(P)$

Tingkat kesetaraan antara pihak laki-laki dalam usahatani padi sawah di Pekon Wonodadi Kecamatan Gading Rejo dalam kontrol terhadap sumber daya memberikan gambaran bahwa laki-laki menjadi pihak yang paling besar peranannya dibandingkan dengan kaum perempuan dengan persentase kontrol sebesar $66,00 \%$. Kegiatan yang dilakukan secara bersama-sama hanya sebesar $8,00 \%$, dan sebesar $26,00 \%$ kegiatan dilakukan secara bersama-sama tetapi didominasi laki-laki yang meliputi kegiatan memutuskan waktu panen, memutuskan waktu tanam, memutuskan untuk menjual atau tidak menjual hasil panen.

\section{Tingkat Kesetaraan dalam Kontrol terhadap Manfaat}

Tingkat kesetaraan dalam kontrol terhadap manfaat untuk melihat bagaimana kontrol lakilaki atau perempuan dalam menentukan keputusan dari manfaat yang diperoleh dari kegiatan usahatani. Kontrol seseorang terhadap manfaat ini menunjukan bagaimana peran atau dominasi seseorang dalam rumah tangga.

Tabel 7. Tingkat kesetaraan dalam kontrol terhadap manfaat pada rumah tangga petani padi sawah di Pekon Wonodadi

\begin{tabular}{lcccccc}
\hline $\begin{array}{l}\text { Kontrol terhadap } \\
\text { Manfaat }\end{array}$ & L & BDL & B & BDP & P & Total \\
\cline { 2 - 7 } & $\%$ & $\%$ & $\%$ & $\%$ & $\%$ & $\%$ \\
\hline $\begin{array}{l}\text { Mengatur alokasi } \\
\text { manfaat }\end{array}$ & 0 & 50 & 50 & 0 & 0 & 100 \\
$\begin{array}{l}\text { Pemenuhan } \\
\text { kebutuhan dasar }\end{array}$ & 20 & 0 & 60 & 20 & 0 & 100 \\
$\begin{array}{l}\text { Pemenuhan } \\
\text { Pendidikan }\end{array}$ & 0 & 20 & 80 & 0 & 0 & 100 \\
$\begin{array}{l}\text { Mengelola } \\
\text { pengeluaran }\end{array}$ & 20 & 0 & 30 & 0 & 50 & 100 \\
$\begin{array}{l}\text { Kontrol kekuatan } \\
\text { politik }\end{array}$ & 100 & 0 & 0 & 0 & 0 & 100 \\
\hline Rata-rata & 28 & 14 & 44 & 4 & 10 & 100 \\
\hline $\begin{array}{l}\text { Keterangan: } \\
\text { Laki-Laki (L), Bersama Dominasi Laki-laki (BDL), Bersama }(B), \\
\text { Bersama Dominasi Permpuan (BDP), Perempuan (P). }\end{array}$
\end{tabular}

Kontrol manfaat meliputi kegiatan mengatur alokasi manfaat, pemenuhan kebutuhan dasar, pemenuhan pendidikan, pengelolaan pengeluaran, dan kontrol kekuatan politik. Tingkat kesetaraan gender dalam kontrol terhadap manfaat menunjukan bahwa terah terjadi kesetaraan antara laki-laki dengan perempuan dengan sebesar $44,00 \%$. Kegiatan usahatani yang padi sawah yang dilakukan secara bersama-sama meliputi kegiatan pemenuhan pendidikan, pemenuhan kebutuhan dasar, mengatur alokasi manfaat, dan mengelola pengeluaran rumah tangga.

\section{Faktor-faktor yang Mempengaruhi Kesetaraan Gender}

Rumah tangga petani padi sawah di Pekon Wonodadi merupakan masyarakat yang didominasi oleh Suku Jawa dengan tingkat pendidikan yang relatif rendah serta dengan tingkat kepatuhan terhadap kebudayaan cukup kuat. Kegiatan sosial kemasyarakatan umumnya mengikuti tradisi yang telah diwariskan secara turun temurun. Kesetaraan gender antara perempuan dan laki-laki dalam beberapa aspek kemasyarakatan masih 
dianggap hal tabu. Terdapat beberapa faktor yan mempengaruhi sulit terjadinya kesetaraan gender antara laki-laki dengan perempuan yang meliputi faktor budaya, pendidikan, ketidakpercayaan diri perempuan, dan kondisi ekonomi rumah tangga petani.

\section{Budaya}

Masyarakat Pekon ini didominasi oleh masyarakat yang bersuku Jawa. Dalam masyarakat Suku Jawa terdapat stereotype pembagian kerja dimana perempuan menguasai peran domestik atau reproduksi yang sifatnya melayani apa yang menjadi kebutuhan dasar keluarga. Perempuan dianggap lebih pantas untuk di dapur dan menghabiskan waktunya di rumah sedangkan kaum laki-laki memiliki kedudukan sebagai pengambil kebijakan dalam rumah tangga (Dalem, 2012).

\section{Pendidikan}

Responden penelitian didominasi lulusan SD. Pengetahuan yang dimiliki masyarakat sangat mempengaruhi pola pikir dan pola perilaku masyarakat itu sendiri. Hal ini sejalan dengan penelitian Fibrianto (2016) dan Hamid et al. (2018) yang menjelaskan bahwa tingkat pendidikan berhubungan dengan tinngkat kesetaraan gender dalam suatu masyarakat.

\section{Ketidakpercayaan diri perempuan}

Budaya dan stereotype peran perempuan yang selalu identik dengan peran domestik. Hal tersebut berpengaruh dengan kepetidakpercayaan diri perempuan dalam perkerjaan yang diluar kebiasaan. Ketidakpercayaan diri perempuan ini menjadi salah satu pemicu dalam gerakan feminism untuk lebih meningktakan posisi dan peran perempuan. Ketika perempuan dapat berkelompok untuk meningkatkan kepercayaam dirinya (Eddayono, 2018)

\section{Kondisi Ekonomi}

Ekonomi dalam rumah tangga dalam kerja dibidang produksi didominasi oleh laki-laki. Kondisi ini membentuk suatu paradigma dimana seorang laki-laki yang sudah memenuhi kebutuhan ekonomi keluarga dianggap lebih tinggi posisinya juga dalam rumah tangga tersebut, sehingga posisi perempuan berada pada tingkat di bawah lakilaki (Laila dan Qudsiyah, 2017).

Selain faktor penghambat, terdapat faktor pendorong kesetaraan gender. Salah satu faktor yang mendorong kesetaraan gender adalah munculnya organisasi perempuan dalam masyarakat yang mendorong kesadaran perempuan untuk mengambil peran penting dalam masyarakat. Kelompok Wanita Tani (KWT) merupakan salah satu bentuk kelompok masyarakat yang mampu menghimpun perempuan untuk berkontribusi dalam usahatani padi sawah. Hal ini sejalan dengan penelitian Hasan dan Matoka (2016); Mutolib, Yonariza. Mahdi, dan Ismono (2016); Yanfika, Listiana, Mutolib dan Rahmat (2019) yang menyebutkan bahwa keberadaan KWT akan meningkatkan peranan kaum perempuan dalam upaya mencapai kesetaraan gender.

\section{KESIMPULAN}

Aktivitas yang dilakukan masyarakat petani padi sawah baik dalam kegiatan produktif, maupun sosial menujukan bahwa laki-laki masih memegang peran utama, sedangkan perempuan hanya memiliki peran dominan dalam kegiatan reproduktif. Temuan ini menunjukan masih terdapat kesetaraan gender dalam rumah tangga petani padi sawah di Pekon Wonodadi. Kesetaraan gender dalam akses dan kontrol terhadap sumber daya dan manfaat menunjukan peran dominan lakilaki, meskipun terdapat satu sisi dimana terhadap kontrol manfaat masih dikatakan seimbang, namun secara umum laki-laki memegang peran dominan dalam akses dan kontrol dalam kegiatan usahatani padi sawah. Faktor-faktor yang memengaruhi kesetaraan gender pada petani padi sawah di Pekon Wonodadi mliputi: faktor budaya, tingkat pendidikan, ketidakpercayaan diri perempuan, dan tingkat ekonomi atau pendapatan rumah tangga petani.

\section{DAFTAR PUSTAKA}

Anggito, A. dan Setiawan, J. 2018. Metodologi Penelitian Kualitatif. Sukabumi: CV Jejak.

Arkaniyati. 2012. Kesetaraan dan keadilan gender dalam usahatani bawang merah, Desa Sidakaton, Kecamatan Dukuhturi, Kabupaten Tegal, Provinsi Jawa Tengah. [Skripsi]. Bogor: Institut Pertanian Bogor. 
BPS Kabupaten Pringsewu. 2019. Kabupaten Pringsewu dalam Angka 2019. Pringsewu: BPS Pringsewu.

BPS Provinsi Lampung. 2019. Provinsi Lampung dalam Angka 2019. Bandar Lampung: BPS Pringsewu.

Dalem, D.N. 2012. Faktor-Faktor Yang Mempengaruhi Bias Gender Penggunaan Kontrasepsi Pada Pasangan Usia Subur di Desa Dawan Kaler Kecamatan Dawan Klungkung. Jurnal Piramida. Vol. VIII No.2: 93-102

Eddayono, Sri Wiyanti. 2018. Hukum Pidana dan Ketimpangan Gender. Jurnal Perempuan. Vol. 23 No. 2.

Fibrianto, A.S. 2016. Kesetaraan Gender dalam Organisasi Mahasiswa Universitas Sebelas Maret Surakarta. Jurnal Analisa Sosial. Vol. 5 (1) : 10-27.

Hamid, M.A. Nurtanto, M. Rahmat, A. Mutolib, A. Nurhaji, S. Fawaid, M. dan Rizal, SU. 2018. The Analysis of Learning Implementation Plan (LIP) in Vocational Subjects Based on 2013 Curriculum. Advances in Social Science, Education and Humanities Research (ASSEHR), volume 161: 27-32

Handayani, T.A. 2015. Mewujudkan Keadilan Gender melalui Perlindungan Hukum terhadap Perempuan. Jurnal Reschtstaat Nieuw. Vol 1 No.1

Hasan, A. dan Matoka, U. 2016. Analisis Kesetaraan Gender dalam Penguatan Kelembagaan di Universitas Halu Oleo. Jurnal Ekonomi. Vol 1 (1) : 33-43

Hubies, AVS. 2010. Pemberdayaan Perempuan dari Masa ke Masa Bogor IPB Press.

Laila, I. dan Qudsiyah, S. 2017. Gender dan Pendidikan Multikulturaldo MTSN Turen Kab. Malang menuju Kiprah "Madrash lebih baik dari Madrasah". Jurnal Perempuan dan Anak. Vol 1. No. 1 : 87110.

Listiana, I. Efendi, I. Mutolib, A. dan Rahmat, A. 2019. The behavior of Extension Agents in Utilizing Information and Technology to Improve the Performance of Extension Agents in Lampung Province. Journal of Physics: Conference Series, 1155 (012004): 1-9.

Manginsela, E.P. 2017. Usahatani Yang Berkeadilan Gender dan Menguntungkan. Agri-sosioekonomiunsrat, 13(3):1-6.
Mantra IB. 2004. Demografi Umum. Pustaka Pelajar. Yogyakarta.

March, Candida et al. 1999. A Guide to Gender-Analysis Framework. Oxford: An Oxfam Publication.

Martiany, Dina. 2012. Implementasi Pengarusutamaan Gender (PUG) seabai Strategi Pencapaian Kesetaraan Gender (Studi di Provinsi Sumatera Utara dan Jawa Tengah). Jurnal Aspirasi. Vol 2 No $2: 122-136$.

Mutolib, A. Yonariza. Mahdi. dan Ismono, $\mathrm{H}$. 2016. Gender inequality and the oppression of women within minangkabau matrilineal society: A Case study of the management of ulayat forest land in nagari bonjol, dharmasraya district, west sumatra province, Indonesia. Asian Women, 32(3): 23-49.

Nurmayasari, I. Mutolib, A. Hudoyo, A. Yanfika. Khoirunnisa, A. Mangesti, RM. dan Rahmadanti, R. 2020. Tingkat Kesetaraan Gender Pada Rumah Tangga Petani Sawi di Pekon Campang Kecamatan Gisting Kabupaten Tanggamus. JSHP: Jurnal Sosial Humaniora dan Pendidikan, 4(1): 21-30.

Pawitasari, Erma. 2015. Pendidikan Khusus Perempuan anatara Kestaraan Gender dan Islam. Jurnal Ilmu Peradaban Islam. Vol. II No. 2: 249-272.

Pratiwi N. 2007. Analisis Gender pada Rumah Tangga Petani Monokultur Sayur (Kasus Desa Sigorogunung, Kecamata Ngagoyoso, Kabupaten Karanganyar, Jawa Tengah). Skripsi. Bogor: Institut Pertanian Bogor. Putri, Sinta Rahmi. 2010. Relasi gender pada rumah tangga petani sayur dataran rendah. [Skripsi]. Bogor: Institut Pertanian Bogor.

Rusni, Syaribulan, dan Nurdin. 2015. Geneologi Gender pada Perempuan Pembuat Ikan Kering. Jurnal Equilibrium Pendidikan Sosiologi, 3(1).

Salman, D, 2017. Dinamika Masyarakat Tani. Makassar: Ininnawa.

Soejipto, Budi. 2010. Manajemen Sumber Daya Manusia : Sebuah Tinjauan Komprehensif (Bagain I). Amara Books. Jakarta.

Unggul, P. 2005. Tingkat Kesetaraan Gender Pada Usahatani Padi di Kecamatan Mlati Kabupaten Sleman. Fenomena.Volume 3 No. 2: 146-159. 
Yanfika, H. Listiana, I. Mutolib, A. dan Rahmat, A. 2019. Linkages between Extension Institutions and Stakeholders in the Development of Sustainable Fisheries in Lampung Province. Journal of Physics: Conference Series, 1155 (01201): 1-9.
Yunus, A., D. Salman, Demmallino, E.B., Viantika, N.M., 2016. Sociotechnical Change and Institutional Adjustment in Paddy Rice Farming During Post Green Revolution in Indonesia. IJAS, Vol.2, Issue 2: 218-227. 